\title{
The Effectiveness of Blended Learning Approach on Essay Writing Subject
}

\author{
Sri Gustiani ${ }^{1, *}$, Evi Agustina Sari ${ }^{1}$, Yusri $^{1}$, Tiur Simanjuntak ${ }^{1}$ \\ ${ }^{1}$ English Department, Sriwijaya Polytechnics, Palembang, Indonesia \\ *Corresponding author. Email: srigustiani@polsri.ac.id
}

\begin{abstract}
This study aimed at investigating the effectiveness of a blended learning approach in learning essay writing subject to the students at English Department, Sriwijaya Polytechnics. It expected to answers the question: is a blended learning approach effective in improving students' essay writings compared to traditional approach? It used a quantitative method both in collecting and presenting the gained data. The data were gained from the pre-test and post-test scores of the experimental and control groups of the participants in learning essay writing. The participants were 44 students whom equally grouped into two groups of learning essay writing: an experimental and a control. The experimental class had a blended learning approach, while the control one had a traditional approach in learning essay writing subject. The results of the tests from the experimental group and the control group were presented in a descriptive form and from the t-test. The findings revealed that it was more effective to use a blended learning approach in improving students' essay writings comparing to the traditional one. The mean of the experimental group increased by 7.7 from pre-test to post-test, while the control group increased only 1.3.
\end{abstract}

Keywords: blended learning, essay writing, higher vocational institution, quantitative method, writing subject

\section{INTRODUCTION}

Studies pertaining the use of computer and communication technology in teaching and learning processes in higher education has revealed that most educators in higher education apply it in the form of the combination of traditional and online learning or blended learning. Some studies reported blended learning brings benefits, namely the efficiency and effectiveness of lecturers and students learning processes [1][2], technology-based practice in educational involvement [3], a substantial and natural evolution for the advancement of learning processes, and flexibility [5][6][7].

Blended learning also takes place in the practices of English for Specific Purposes (ESP) in higher vocational institution [8]. It was reported to bring benefits both for the educators as the ESP teachers, and the students as the ESP learners. It is rich in pedagogy to meet the set vocational learning outcomes [9][10][11]. On the other hand, learners of ESP experience the innovative use of technology in information and communication in studying ESP and the learning engagement outside the classroom [12][13][14].

In Indonesia, the goals of ESP courses are focussed on developing students' skills in academic and subject-specific of writing, reading, listening and communicative proficiencies. The results of the learning processes basically include some components like the comprehension in listening and academic texts, the knowledge of vocabularies and terms, as well as the fluency of communicative and presentation skills in their field [15].
One example of the course to support this aim is English academic writing which is also taught to English Department at Sriwijaya Polytechnic (Polsri). English Department in Polsri focuses on the field of hospitality industry as the vocational study. This lesson is taught in series as Writing using Process Genre Model [16] with interdisciplinary learning materials [17]. The goals of students in this writing series are the ability to compile on job training and final reports, and also reports of working to be communicated effectively to other parties in their future working fields.

Choosing Writing subject as the focus of this research was based on the following four reasons. First, the learners of Writing for essay were students in higher semesters, who were having on job training program. They were also in the time to write the reports of their on job training and final project. During their job training and final project consultation, some of the learners could not attend onsite classes accordingly due to the supervisory. Second, the students have completed Computer 1-2 subjects which provided sufficient knowledge to operate computer for onsite and online learning. Third, the goals of Writing for essay in upper semesters were required the students to be able to develop kinds of essay, such as descriptive, narrative, opinion, comparison \& contrast, cause \& effect, especially for students who need to write reports for their on-job training or final project. Finally, the students share the same age who were born in year 1998-2000. This type of digital natives' generation is also known as Gen Y millennial generation who uses and familiar with digital technologies in media communications [18]. 
Having deep discussion about blended learning at higher education and ESP at polytechnic, it was worthy to study the effectiveness of a blended learning program for an ESP subject. In this research, the blended learning program was adapted from [19], using Polsri online learning media, i.e., Learning Management System (LMS) on the basis of Moodle. The Writing learning materials were developed using the framework of [20] and [21] academic writing books. Additionally, the content of the Writing subject was developed in accordance of the student's hospitality subjects using interdisciplinary approach, e.g.: Tour and Travel Management; Working Security and Safety; Customer Service Psychology; and Entrepreneurships.

\section{LITERATURE REVIEW}

\subsection{Blended Learning}

Blended learning is a setting of e-learning processes in which the learning materials and learning instructions are personalised based on the needs of the group learners [22]. The word 'blend' means to blend or combine both traditional learning of face to face and online learning which applies a variety of multi-media in an applicable way to solve learning and teaching processes. [23] pointed out in his study about the rapid growth of blended learning as the assembling of traditional learning and online learning. The blended learning is gained in the intersection of these two existing learning approaches.

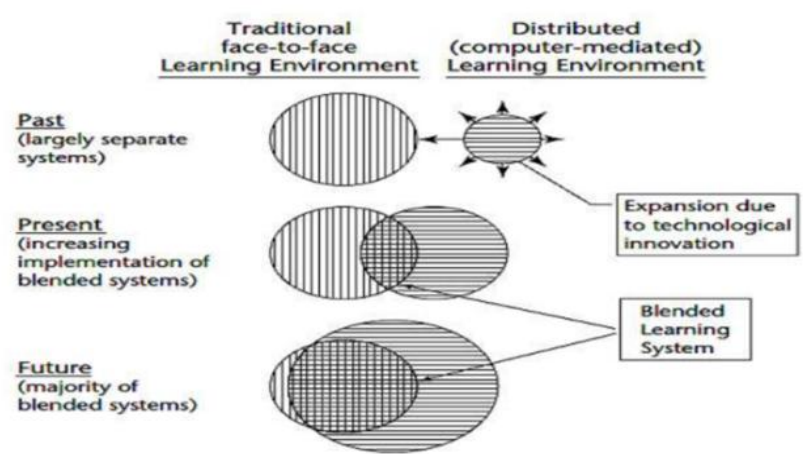

Figure 1 Emerging of blended learning approach in the intersection of traditional face-to-face and computer mediated learning system

\subsubsection{Characteristics of Blended Learning}

Some studies had provided some characteristics of the emerging blended learning as an approach of teaching and learning.

\subsubsection{No Time and Place Restriction}

As students can access the learning material or doing assignment from a distance, blended learning offers an environment where students can study regardless time and place limitation. It extends the learning space and opportunities for teaching and learning processes [24] [25].

\subsubsection{More Control over Own Learning}

Having more flexible time in conducting the learning process, students are able to control their own learning time and learning styles. As students have various individual preferences in learning, this approach supports learning diversity. They can manage how and when the best time for them to study. Moreover, they also have an alternative way to control their interaction with teachers and friends for the purpose of learning a subject [24] [25][26][27].

\subsubsection{Technology Involvement}

The instruction and features of blended learning made students exposed more to e-learning experience. For instances, they could learn how to uploading and downloading files or doing and submitting assignment online, This situation lead students become familiar and literate to ICT skills and knowledge [28][29][30][31][10].

\subsubsection{Economical}

Blended learning is proven to reduce instructional delivery costs because students as a subject learners could study it without travelling to a class. Furthermore, learning materials are accessible online, which in turn, could reduce paper, printing, or photocopying costs [32][10][33].

\subsection{Design Process}

[28] argued that, designing a blended learning is a crucial assignment for teachers as it required thoughtful selection and organisation of learning materials with proper information technology knowledge. It also includes proper presentation as well as learning activities, assignment, and assessment in accordance to the students' needs. This research adopted the blended learning designed by [33]. It constructed as a 16-week blended learning which breakdown into course onsite, main components online, and onsite or online feedback. This cycle was repeated until the studying week complete. 


\subsection{Writing}

Some scholars have defined writing as follow. [34] argued that writing is a conceptual work starting from inventing ideas and designing ways to express the ideas, to organizing the ideas and the expression ways into sentences and paragraphs. In line with [35] stated that as a process of thoughts documentation, writing required communicative social activity in which the product of the mental work is readable by all readers. Furthermore, [36] defined it is not merely as a process for combining words into sentences, and sentences into paragraph, but it required a technic in generating, organising, translating ideas into a coherent, cohesive, and informative text.

Writing also requires knowledge and skills, [37] mentioned that writing processes involve the knowledge of using orthographic symbols as well as skills in selecting and organising them in accordance to a particular purpose. In addition to the previous definition, [38] added that writing requires the knowledge in using written language devices such a syntax, vocabulary, various clause types, complex phrases, and tenses. However, other scholars pointed out the written language devices as mechanics of writing, described as follow.

First, punctuation, as argued by [39], was divided into two marks: internal and end. Internal marks are used within the sentence, and end marks refers to punctuation at the end of sentences. Additionally, [40] divided the punctuation marks into three marks: within words like apostrophes, between words like hyphens, and end words like question mark. Second, capitalization was defined by [41] as another form of punctuation to guide readers' eyes and mind along the text. Capitalization basically is used to start names and sentences. It is also used in acronyms and initials. Third, coherence as glue to stick ideas in a writing together was defined by [42] to have importance in relating preceding and following sentences. They proposed four writing tools for better coherence: words, ideas, and phrases repetition, transitional markers, pronoun, and synonyms. Finally, cohesion was defined by [43] as sentences liker in a text. They refer it as conjunction, substitution, ellipsis, references, and lexical. Nevertheless, as cohesion is recognised easily from the text surface, it has to identify directly.

\subsection{Previous Study}

This study is mapped in accordance to its previous study in academic to find the place where this study might be suitable to fill the gaps of previous research. The following three previous studies were conducted in order to find the effectiveness of blended learning as learning media. All the subjects were English language subject in the position of EFL, however, none of them pointed out the ESP Writing Essay subject for vocational students. [44] studied the effectiveness of Facebook and peer-assessment integration to academic English writing via a blended learning approach. The results indicated that Facebook could enhance students' interest and motivation in learning academic English writing, hence, improve students' writing achievement. Next, [45] also examined the effectiveness of blended learning approach in teaching writing to students of second grade preparatory school. He concluded from his study that blended learning had a big impact on the participants writing skills. [46] in 2017 investigated the effectiveness of online discussion group in improving writing skills of first year students' of a secondary school. It was revealed that blended learning improved the students' mechanics of writing skills. These three studies lied the basic foundation that it was worthy to fill the gaps of the previous studied. It was to conduct a study about examining a blended learning in qualitative method for an ESP subject (Writing) for students at higher vocational school.

\section{METHOD OF RESEARCH}

\subsection{Research Design}

This study apply an experimental quantitative research. It tested the blended learning model to determine whether it affected the dependent variable. In this case, the influence of the blended learning of process genre model in improving the writing skills of the students was tested [47].

\subsection{Research Setting}

This research was conducted at English Department, Polsri which located on Jalan Srijaya Negara, Bukit Besar, Palembang 30139. English Department was supported by Hot Spot area. All the students could surf and access the internet easily. This place was chosen due to the purpose of the study, to investigate the effectiveness of blended learning approach in Writing subject of upper semester students at English Department, Polsri. It was conducted during one semester studying period from February to July 2019. There were 16 weeks of active studying week for one semester; each meeting in a week was lasted for 150 minutes for the onsite learning for the participants.

\subsection{Population and Sample}

This research involved the students of semester six at English Department as a population in Writing subject. The entire samples were taken using purposive sampling in which the samples were chosen purposively due to some certain characteristics [47]. The purpose of the sample selection was because the sixth semester students who have basic writing skills 1 and 2, and have completed computer class 1 and 2. Each sample class had the same characteristics in the number of students (22 students/class), basic knowledge of writing skills, together 
mixed genders, culture and users of English as a foreign language. All the classes in the sample of the study were supported by internet device. In doing the assignment the student must browse and find out the information from the internet. Most of them have ability to use the internet well. They were two classes of English Department students in semester 6 year 2018/2019. The two classes were 6BB as an experimental class that received the blended learning approach and 6BA as a control class received traditional learning. Both classes had pre-test and post-test using Instrument for Pre-Test and Post-Test adapted from [16][20][25]. to know their scores to investigate the effectiveness of blended learning for Writing subject.

\subsection{Data Collection}

To collect the data, an essay writing skill test was adapted from [20][21]. Students are asked to write essays as in the summative evaluation for pre-test and post-test. The scores were given based on the assessment criteria with a range of 1-100. The criteria were adopted from [48]. The essay assessment criteria consisted of five components: Organization, Content, Vocabulary, Grammar, and Mechanics, as shown below. In this research, testing the validity of the rubric of paragraph writing skills was not done empirically but based on a theoretical validity test conducted rationally by experts [48][49]. To see the reliability of the paragraph writing skill instrument was done through reliability among the assessors (interrater reliability). In the practice, it involved two assessors who both are from the English Department.

The results of the test from the experimental group and the control group were presented in a descriptive form and from the t-test. Researchers calculated the differences; pretest and post-test in the experimental and control groups. The data were analyzed by using SPSS references from [50][51].

\section{FINDINGS AND DISCUSSION}

\subsection{Findings}

To answer the research question: Is a blended learning approach effective in improving student essay writing compared to traditional approach? determines the effectiveness of blended learning in improving the participants' essay writing skills compared to traditional approach. Table I presents the pre-test and post-test scores from the experimental group. The Table II presents the pre-test and post-test scores from the control group. Both tables from the experiment and control groups shows the students' pre-test and post-test scores and its percentage in learning writing. The experimental group had blended learning approach and control group had traditional approach.
Table 1 Pre-test and post-test scores of the experimental group

\begin{tabular}{|c|c|c|c|c|}
\hline \multirow{2}{*}{$\begin{array}{c}\text { Valid } \\
\text { Score }\end{array}$} & \multicolumn{2}{|c|}{ Pre-test } & \multicolumn{2}{c|}{ Post-test } \\
\hline 85 & frequency & $\%$ & frequency & $\%$ \\
\hline 80 & 0 & 0.0 & 2 & 4.8 \\
\hline 75 & 4 & 0.0 & 4 & 19.0 \\
\hline 70 & 6 & 27.3 & 3 & 14.3 \\
\hline 65 & 6 & 27.3 & 3 & 14.3 \\
\hline 60 & 5 & 22.7 & 0 & 0.0 \\
\hline 55 & 1 & 4.5 & 0 & 0.0 \\
\hline Total & 22 & 100.0 & 22 & 100.0 \\
\hline Mean & 66.6 & \multicolumn{2}{c|}{74.3} \\
\hline
\end{tabular}

Table 2 Pre-test and post-test scores of the control group

\begin{tabular}{c|c|c|c|c|}
\multirow{2}{*}{$\begin{array}{c}\text { Valid } \\
\text { Score }\end{array}$} & \multicolumn{2}{c}{ Pre-test } & \multicolumn{2}{c}{ Post-test } \\
\cline { 2 - 5 } & frequency & $\%$ & frequency & $\%$ \\
\hline 85 & 0 & 0.0 & 0 & 0.0 \\
\hline 80 & 0 & 0.0 & 0 & 0.0 \\
\hline 75 & 2 & 9.1 & 2 & 9.1 \\
\hline 70 & 4 & 18.2 & 5 & 22.7 \\
\hline 65 & 6 & 27.3 & 9 & 40.9 \\
\hline 60 & 9 & 40.9 & 6 & 27.3 \\
\hline 55 & 1 & 4.5 & 0 & 0.0 \\
\hline Total & 22 & 100.0 & 22 & 100.0 \\
\hline Mean & \multicolumn{2}{|c|}{64.3} & \multicolumn{2}{|c|}{65.6} \\
\hline
\end{tabular}

It is shown in the pre-test of the experimental group column that before the students in this group had blended learning approach, the highest score was 75 , the lowest score was 55, and with the mean was 66.6. After having blended learning treatment, the students indicated to have improvement in their essay writing skill because all the scores in post-test increased, the students' highest score increased into 85 , the lowest became 65 , and the mean was 74.3.

Meanwhile, in the Control Group, the students' highest score before taught using conventional or traditional approach was 75 , the lowest score was 55 , and the mean was 64.3. After the students got the traditional learning approach, their highest score was still on 75 , the lowest score increased into 60 , and the mean score was 65.7. The comparison of the mean numbers from the experimental and control groups shows that the mean in experimental group increased by 7.7 from pre-test to post-test. In contrast, the mean in the control group only increased by 1.3 from pre-test to post-test. This shows that applying blended learning approach is more effective in improving students writing essay competence.

Relating the students' scores to the assessment criteria by [21] in which the scores were converted into: (1) perfect (100-85); (2) very good to good (84-68); (3) average to sufficient (67-46); and (4) weak to very weak (45-30), the results were presented in the following Table 3 and 4. 
Table 3 The conversion of the frequency and percentage of students' scores in the experimental group

\begin{tabular}{c|c|c|c|c|c|} 
Score & Qualification & \multicolumn{2}{c}{ Pre-test } & \multicolumn{2}{c}{ Post-test } \\
\cline { 5 - 6 } Analysis & Criteria & Freq & \% & Freq & $\%$ \\
\hline $100-85$ & Prefect & 0 & 0.0 & 2 & 0.94 \\
\hline $84-68$ & $\begin{array}{c}\text { Very Good to } \\
\text { Good }\end{array}$ & 10 & 45.5 & 17 & 77.3 \\
\hline $67-46$ & $\begin{array}{c}\text { Average to } \\
\text { Sufficient }\end{array}$ & 12 & 54.5 & 3 & 13.3 \\
\hline $45-30$ & $\begin{array}{c}\text { Weak to Very } \\
\text { Weak }\end{array}$ & 0 & 0.0 & 0 & 0.0 \\
\hline & & & & & \\
\hline
\end{tabular}

Table 3 above shows that before the students in experimental group had blended leaning treatment, there was none of them in perfect category, and however it has 10 students $(45.5 \%)$ in very good to good qualification, there were 12 of them $(54.5 \%)$ in average to sufficient qualification. Having post of the blended learning approach, 2 students $(0.94 \%)$ in this group were indicated to have perfect qualification, 17 students (77.3) were in very good to good qualification, and 3 students (13.3\%) were in average to sufficient category. None of the students was in weak to very weak qualification from pre and post blended learning approach.

Table 4 The conversion of the frequency and percentage of students' scores in the control group

\begin{tabular}{l|l|l|l|l|l|}
\multirow{2}{*}{$\begin{array}{l}\text { Score } \\
\text { Analysis }\end{array}$} & Qualification & \multicolumn{2}{l}{ Pre-test } & \multicolumn{2}{c}{ Post-test } \\
\cline { 3 - 6 } & Criteria & Freq & $\%$ & Freq & $\%$ \\
\hline $100-85$ & Prefect & 0 & 0.0 & 0 & 0.0 \\
\hline $84-68$ & $\begin{array}{l}\text { Very Good to } \\
\text { Good }\end{array}$ & 6 & 27.3 & 7 & 31.8 \\
\hline $67-46$ & $\begin{array}{l}\text { Average to } \\
\text { Sufficient }\end{array}$ & 16 & 72.2 & 15 & 68.2 \\
\hline $45-30$ & $\begin{array}{l}\text { Weak to Very } \\
\text { Weak }\end{array}$ & 0 & 0.0 & 0 & 0.0 \\
\hline
\end{tabular}

Comparing to the students in control group, before they had traditional approach none of them in perfect category, 6 students $(27.3 \%)$ were in very good to good category, and 16 of them $(72.7 \%)$ was in average to sufficient category. After having traditional approach, still none of them was in perfect category, 7 students $(31.8 \%)$ of this group were in very good to good category, and 15 students $(68.2 \%)$ were in average to sufficient category. None of the students was in weak to very weak category.

The percentage in Table III also indicated that after having blended learning approach the number of the students in experimental group with perfect to good qualification was $86.7 \%$ (19 students). Whereas, the numbers of the students in control group (Table IV) with the same qualification was $31.8 \%$ (7 students). The comparison of the student's percentage in perfect to good category between the experimental and control group implies that blended learning approach were more effective to improve students writing essay rather than traditional approach. By having the numbers in all table, it has determined the effectiveness of blended learning approach comparing to traditional approach in learning writing to students of English Department at Polsri.

\subsection{Discussion}

The following discussion explores some advantages of learning by blended learning approach in order to increase students learning achievement: the easiness to be accessed, information technology knowledge and experiences enrichment, flexible time, save money and paper, and comfort. First, being able to access the online learning material and do the online assignment, students are provided by a new learning environment in which they can study and complete their assignment wherever and whenever if it is possible. This is in line with [25] argument that blended learning exposed students as learners of a subject to the learning condition where there is no time and place restriction. [24] claimed that the possibility to be accessed out of the class hours makes blended learning approach broaden the opportunity and places available for the learners to have teaching and learning processes of a the subject.

Second, implementing blended learning as a part of online learning processes exposes students to the enhancement of their information and technology knowledge and experience. The features and instructions of the program ensure students ability to use technology successfully for learning and teaching processes [30]. Operating the online learning system provides more time to get familiar with the instructions, enhances their information technology skills and their e-learning experiences [31][10]. Students could learn instructions i.e.: accessing a file, submitting assignment, and communicating with other students and teachers [24][28][29][26][33].

Then, the availability to be accessed online without time restriction makes blended learning approach giving more flexible time in learning a subject. Students as the online learners become independent learners as they have time to control their studying times and over their own learning. They have more time to read and understand a topic and do the assignment in their most convenience time. Some scholars agreed that having more time in learning a subject make the students to be able to upgrade the engagement and responsible to their learning. This situation leads to the better achievement [24][25][31][33].

Next, the uploaded learning materials and assignment give the students chance to read and study them online. It means these learning and teaching processes do not require the students to have the printed copy of the teaching and learning materials. Blended learning could reduce paper and photocopying costs because all teaching and learning documents are uploaded and easily accessible to the students. It also reduce the instructional delivery costs because students do not need to travel to class [32][10][33]. 
Finally, blended learning approach is reported being able to integrate the weakness and the strength of traditional and online learning approaches. For example, students who have difficulty in communication in classroom, would find easier to communicate online. [25] argued that this type of learning could facilitate some types of learning types, personal characteristics and individual differences. In line with the previous scholars, [31] also claimed that blended learning approach is a solution for various learning styles, learning proficiency, as well as learning ability of students in a class. Having blended learning facilitates students who prefer to type on their laptops or smartphones rather than on paper and pens [24][10].

\section{CONCLUSION}

This study has illuminated the effectiveness of blended learning approach on writing subject to students at English Department at Sriwijaya Polytechnics through quantitative method. The effectiveness in experimental group was shown by the gap of the mean numbers of pre-test and post-test. Before having blended learning approach the mean was 66.6 and after was 74.3. It was increased by 7.7 from pre-test to post test. Comparing to the control class, which had traditional approach, the mean-number of the pre-test was 64.3 and post-test was 65.7 . The mean number only increased by 1.3 .This shows that applying blended learning approach is more effective in improving students writing essay competence. However, it is suggested to design a better blended learning which applicable in weak/bad internet access areas.

\section{REFERENCES}

[1] R. D. Harrison, \& H. Kanuka. Blended learning: Uncovering its transformative potential in higher education. Internet and Higher Education 7, 2004, pp.95-105.

[2] C. Williams. Learning on-line: A review of recent literature in a rapidly expanding field. Journal of Further and Higher Education, 26(3), 2002, pp.263-272.

[3] M. Hicks, I. Reid, \& R. George. Enhancing on-line teaching: Designing responsive learning environments. The International Journal for Academic Development, 6(2), 2001, pp. 143-151.

[4] S.R. Hiltz, \& M. Turoff. The digital society education goes digital: The evolution of online learning and the revolution in higher education. Communications of the ACM., 48(10), 2005, pp. 59-67.
[5] E. Masie. The blended learning imperative. In C. J. Bonk \& C. R. Graham (Eds.), Handbook of blended learning: Global perspectives, local designs (pp. 22-26). San Francisco, CA: Pfeiffer, 2006.

[6] J. Massy. The integration of learning technologies into Europe's education and training system. In C. J. Bonk \& C. R. Graham (Eds.), Handbook of blended learning: Global perspectives, local designs (pp. 419-431). San Francisco, CA: Pfeiffer, 2006.

[7] B. Ross, \& K. Gage. Global perspectives on blended learning: Insight from WebCT and our customers in higher education. In C. J. Bonk \& C. R. Graham (Eds.), Handbook of blended learning: global perspectives, local designs (pp. 155-168). San Francisco, CA: Pfeiffer, 2006.

[8] L.J.E..Larsen. Teacher and students' perspectives on a blended learning intensive English program writing course. Graduate thesis, Iowa State University, 2012.

[9] C. Banditvilai. Enhancing Students' Language Skills through Blended Learning. The Electronic Journal of e-Learning (14)3, 2016, (pp220-229).

[10] R.T. Osguthorpe， \& C.R. Graham. Blended learning environments: Definitions and directions. The Quarterly Review of Distance Education, 4(3), 2003, pp. 227-233.

[11] J. Stein, \& C.R. Graham. Essentials for blended learning: A standards-based guide. New York and London: Routledge, 2014.

[12] M. Gaebel, V. Kupriyanova, R. Morais, \& E. Colucci. E-learning in European higher education institutions. Brussels: European University Association, 2014.

[13] C.R. Graham, S. Allen, \& D. Benefits and challenges of blended learning environments. In M. Khosrow-Pour (Ed.) Encyclopaedia of information science and technology (pp. 253-259). Hershey, PA: Idea Group, 2005.

[14] R. Sharpe, G. Benfield, G. Roberts, \& R. Francis. The undergraduate experience of blended elearning: A review of UK literature and practice. The Higher Education Academy, 2006.

[15]FDPNI (Forum Direktur Politeknik Negeri se Indonesia). Capaian Pembelajaran Program 
StudiPoliteknik.(Toha,I. S. Editor). Jakarta: KomisiPembelajaran FDPNI, 2016.

[16] E. Agustinasari, S. Gustiani, Yusri, \& T. Simanjuntak. Teaching writing to the English Department Students of Sriwijaya State Polytechnics through a Process Genre Model Approach. Journal of English in Academic and Professional Communication JEAPCo. 5(2), 2018, pp.43-56.

[17] T. Simanjuntak, E. Agustinasari, S. Gustiani, \& Yusri. The implementation of interdisciplinary approach to Writing 1 subject for students of English Department. Majalah Ilmiah Pengembangan Rekayasa dan Sosial Politeknik Negeri Semarang, ORBITH, 14(1), 2018, pp. 2227.

[18] N. Howe, \& W. Straus. Millennials Rising: The Next Great Generation. New York: Knopf Doubleday Publishing Group, 2009.

[19] S. Tuomainen. A blended learning approach to academic writing and presentation skills. LLCE 3(2), 2016, pp. 33-55.

[20] A. Oshima, \& A. Hogue. Introduction to Academic Writing (3rd Ed.). New York, US: Pearson Longman, 2007.

[21] Savage, A., \& Mayer, P. 2005. Effective Academic Writing Book 2-The short essays. England, UK: Oxford Press.

[22] NACOL. Fast facts about online learning (Issue report,1-6). Vienna: North American Council for Online Learning. Retrieved March 5th, 2013, from http:// www.NACOL. org

[23] C. R. Graham.. Blended learning systems: Definition, current trends, and future directions. In The handbook of blended learning: Global perspectives, local designs, ed. C.J.Bonk and C.R. Graham, 3-21. San Francisco: Pfeiffer. Retrieved on March 23rd, 2013 from http://www.academia.edu/563281/Blended_learnin g_systems_Definition_current_trends_and_future_ directions

[24] A. I. Al Fiky. Blended Learning: Educational Design, Multi-media, Creative Thinking. Amman (Jordan): Dar Athaqafa for publishing and distribution, 2011.
[25] A. Finn, \& M. Bucceri. A case study approach to blended learning. Los Angeles: Centra Software. Retrieved March 3rd, 2013 from http://www. conferzone.com/ resource/wp/CaseStudy_Blende dLearning.pdf.

[26] V. J. Gamble. The effectiveness of blended learning for the employee. Dissertation Unpublished. Fielding Graduate University, 2005.

[27] R. H. Huang, Y .L. Zhou, \& Y. Wang. Blended Learning: Theory into Practice. Beijing: Higher Education Press, 2006.

[28] G. M. Billigmeier. Blended Learning: Design and Implementation. Retrieved on March 26th, 2013 from

http://imet.csus.edu/imet10/portfolio/billigmeierg/b illigmeier/ ROLFinal.pdf, 2011.

[29] D. Bath, \& J. Bourke. Getting started with blended learning. Australia: Griffith Institute for Higher Education, 2010.

[30] J. Hofmann. Top10ChallengesofBlendedLearning. Retrieved March 23rd, 2013 from http://www. trainingmag.com/article/soapbox-top-10challenges-blended-learning, 2011.

[31]M. Kendall. Teaching online to campus-based students: The experience of using WebCT for the community information module at Manchester Metropolitan University. Education for Information, 19(4), 2001, pp. 325-346.

[32] C. Dziuban, J. Hartman, F. Juge, P. Moskal, \& S. Sorg. Blended learning enters the mainstream. In C. J. Bonk \& C. R. Graham (Eds.). The handbook of blended learning: Global perspectives, local designs (pp. 3-21). San Francisco: Pfeiffer, 2006.

[33] Sharma, Pete \& Barrett, Barney. Blended Learning: Using technology in and beyond the language classroom. London: Macmillan Publishers Limited, 2007.

[34] M. Sokolik, Writing. Practical English Language Teaching. Edited by D Nunan. New York: McGraw-Hill, 2003, pp. 87-108.

[35] E. Olshtain, E. Functional tasks for mastering the mechanics of writing and going just beyond. In $\mathrm{M}$. Celce-Murcia (Ed.), Teaching English as a second or foreign language (3rd ed., 207-217). United Sates: Heinle \& Heinle, 2001. 
[36] J.C. Richards, \& W.A. Renandya, (Eds.). Methodology in language teaching: An anthology of current practice (5thed.). Cambridge: Cambridge University Press, 2005.

[37] K.M. Johnstone. Effects of Repeated Practice and Contextual-Writing Experiences on College Pupils' Writing Skills. Journal of educational psychology, 94(2), 2002, pp. 305-313.

[38] J.C. Richards. Second Language Writing. Ken Hyland: Cambridge Language Education, 2003.

[39] J. Angelillo, J. " A Fresh Approach to Teaching Punctuation: Helping Young Writers Use Conventions With Precision", New York: Scholastic, Inc, 2002.

[40] T. Sun. Read Me First! A Style Guide for the Computer Industry, Chapter One. Second Edition., New Jersey: Prentice Hall, 2003.

[41] G. King. " Good Writing Guide". Updated ed., Glasgow: Harper Collins Publishers, 2003.

[42] R.C. Gebhardt \& D. Rodrigues. Writing processes and Intentions. America: D. C. Health and company, 1989.

[43] M. Halliday, \& R. Hasan. Language, context, and text: Aspects of language in a social semiotic perspective. Deakin: Deakin University, 1985.

[44] R. Shih. Can Web 2.0 technology assist college students in learning English writing? Integrating Face book and peer assessment with blended learning. Australasian Journal of Educational Technology, 27(5) ,2011, pp. 829-845.

[45]E. A. A. Sayed. The Effect of Using Electronic Portfolios on Developing the English Language Writing Skills for Second Grade Preparatory School Students. Retrieved April 3rd, 2013 from http://srv3.eulc.edu.eg/eulc_v5/libraries/start.aspx.

[46] A. A. E. Kaoudi. The Effectiveness of Internet Blended Discussion Group on Developing Some Composition Writing Skills of First Year Secondary School Students, 2007. Retrieved April 3rd, 2013 fromhttp://srv3.eulc.edu.eg/eulc_v5/libraries/start.a $\operatorname{spx}$

[47] J. Creswell. Educational Research: planning, conducting, and evaluating quantitative and qualitative research. (4th Ed.). New York, USA: Pearson Education Inc, 2012.

[48] S. C. Weigle. Assessing Writing. UK: Cambridge University Press, 2009.

[49] L. J. Zweir, \& M. Pike-Baky. Interaction 1: sentence development and introduction to paragraph writing. Singapore: McGraw-Hill, 2007.

[50] A. Filed. Discovering Statistics Using IBM SPSS Statistics (4thEd.). London, UK: SAGE Publication, 2013.

[51] J. Pallant. SPSS Survival Manual (5thEd.). Sydney, Australia: Allen \& Unwin Co, 2013. 